\title{
Rhapidosomes from Aquaspirillum itersonii: disruption and subsequent renaturation and characterization of the component proteins
}

\author{
Mehran Pazirandeh, ${ }^{1}$ Jeffery Deschamps, ${ }^{2}$ Subash Baral, ${ }^{3}$ \\ Rachael Owlett, ${ }^{3}$ Angeli Aggerwal' and James R. Campbell ${ }^{1}$
}

Author for correspondence: Mehran Pazirandeh.Tel: +1202404 6073. Fax: +1 2027679594.

1 Center for Biomolecular Science and Engineering, Naval Research Laboratory, Washington, DC 20375, USA

2 Laboratory for the Structure of Matter, Naval Research Laboratory, Washington, DC 20375, USA

3 GeoCenters, Inc., Ft Washington, MD 20744, USA

\begin{abstract}
Rhapidosomes, tubular proteinaceous microstructures found in a variety of bacteria and algae, are resistant to disruption by many denaturing agents. They have potential application as a biomaterial and may also serve as a model for the study of self-assembly. Several reagents were tested for their ability to disrupt rhapidosomes isolated from Aquaspirillum itersonii into their component proteins. Only treatments with $0.1 \mathrm{M}$ hydrochloric acid and $6 \mathrm{M}$ guanidinium hydrochloride were found to disrupt rhapidosomes. A protocol was developed to renature the disrupted component proteins using rapid dilution and subsequent dialysis of the residual guanidinium hydrochloride. The renatured proteins were shown to have secondary structure as determined by circular dichroism. Furthermore, upon renaturation the two component proteins interacted with each other to form a complex of molecular mass $>2500 \mathrm{kDa}$. This complex, which may be a precursor in the pathway to rhapidosome formation, is currently being used to study the self-assembly process of these unique structures in vitro.
\end{abstract}

Keywords: Aquaspirillum itersonii, thapidosomes, protein self-assembly, biomaterials

\section{INTRODUCTION}

A variety of bacteria and algae have been described which contain proteinaceous nanometre-scale tubular structures called rhapidosomes (Correl \& Lewin, 1964; Chang \& Allen, 1974). Although rhapidosomes were once thought to be derived from defective phage particles, Evers \& Murray (1980) compared rhapidosomes and phage tail particles from Aquaspirillum itersonii and found them to be composed of distinct protein components and not related. The function and mode of assembly of these structures are currently unknown. Although rhapidosomes are composed of protein subunits, they exhibit a remarkable stability to a variety of extreme conditions such as treatment with $\mathrm{HCl}$, urea, guanidinium hydrochloride $(\mathrm{GHCl})\left(25^{\circ} \mathrm{C}\right.$ ), and a range of organic solvents (Delk \& Dekker, 1972). The only treatments currently known to disrupt these structures are boiling in SDS or, as reported by Delk \& Dekker (1972), treatment with $10 \mathrm{M} \mathrm{GHCl}$ at $100{ }^{\circ} \mathrm{C}$ for $10 \mathrm{~min}$ or with $0.1 \mathrm{M} \mathrm{NaOH}$ at room temperature for $24 \mathrm{~h}$. The remarkable stability of rhapidosomes is unique and different from some of the other

Abbreviations: $\mathrm{GHCl}$, guanidinium hydrochloride; 2-ME, 2-mercaptoethanol. self-assembling molecules (e.g. microtubules) which disassemble into their component proteins under milder conditions (Avila, 1990).

The extreme stability of rhapidosomes makes them of potential use as a novel biomaterial (Pazirandeh et al., 1992). They may also serve as a model for the study of selfassembly. We recently reported on the protein composition of rhapidosomes from $A$. itersonii (Pazirandeh \& Campbell, 1993). These structures were found to be composed of two proteins, of molecular mass $53 \mathrm{kDa}$ and $29 \mathrm{kDa}$. As a prelude to studying the self-assembly process of these structures in vitro we report here on the disruption of thapidosomes with $\mathrm{GHCl}$, and characterization of the renatured protein complex.

\section{METHODS}

Materials. A. itersonii was obtained from the ATCC (Rockville, MD, USA). Pre-cast polyacrylamide gels $[4-20 \%(\mathrm{w} / \mathrm{v})$ Tris/ glycine and isoelectric focusing (IEF)] were from Novex. Molecular mass markers were obtained from Bio-Rad; they included phosphorylase $b, 97 \cdot 4 \mathrm{kDa}$; bovine serum albumin, $66.2 \mathrm{kDa}$; ovalbumin, $45 \mathrm{kDa}$; carbonic anhydrase, $31 \mathrm{kDa}$; soybean trypsin inhibitor, $21.5 \mathrm{kDa}$; and lysozyme, $14.4 \mathrm{kDa}$. pI markers and all other chemicals were from Sigma and were of reagent grade or better. The $\mathrm{pI}$ markers used were amylo- 
glucosidase, pI 3.6; trypsin inhibitor, pI 4.6; lactoglobulin, pI 5.1; carbonic anhydrase II, pI 5.9; carbonic anhydrase I, pI 6.6; myoglobin, pI 7.2; lactic dehydrogenase, pI 8.6; and trypsinogen, pI $9 \cdot 3$.

Bacterial growth and purification of rhapidosomes. The procedures for bacterial growth and the purification of rhapidosomes were as previously described (Pazirandeh \& Campbell, 1993).

SDSPAGE, native PAGE and IEF. SDS-PAGE was performed as described previously (Pazirandeh \& Campbell, 1993) according to the method of Laemmli (1970). Native gels were electrophoresed as described for SDS-PAGE, with the exception that the running buffer and sample buffer did not contain SDS and the samples were not boiled. IEF electrophoresis was performed according to the manufacturer's instructions (Novex). The anode buffer was $10 \mathrm{mM}$ phosphoric acid and the cathode buffer was $20 \mathrm{mM}$ lysine and $20 \mathrm{mM}$ arginine. Sample buffer contained $40 \mathrm{mM}$ lysine, $40 \mathrm{mM}$ arginine and $30 \%(\mathrm{w} / \mathrm{v})$ glycerol. The gels were electrophoresed at $100 \mathrm{~V}$ for $1 \mathrm{~h}, 200 \mathrm{~V}$ for $1 \mathrm{~h}$, and $500 \mathrm{~V}$ for $30 \mathrm{~min}$.

Disruption of rhapidosomes into component proteins. Purified thapidosomes were treated with the following reagents: $0.1 \mathrm{M} \mathrm{NaOH}, 0.1 \mathrm{M} \mathrm{HCl}, 8 \mathrm{M}$ urea, $6 \mathrm{M} \mathrm{GHCl}$, chymotrypsin $(1 / 20, w / w)$ and $n$-butanol. Incubation was performed at a protein concentration of $1 \mathrm{mg} \mathrm{ml}^{-1}$ for $2 \mathrm{~h}$ at $25^{\circ} \mathrm{C}$ except for $6 \mathrm{M} \mathrm{GHCl}$, which was incubated at $80^{\circ} \mathrm{C}$ for $2 \mathrm{~h}$. Following incubation, a portion of the sample was examined by transmission electron microscopy as described below. To the remainder an equal volume of solubilization buffer was added and the sample was divided into two fractions. One fraction was boiled and the other kept at room temperature before analysis by SDS-PAGE as described above.

Renaturation of $\mathrm{GHCl}$-treated rhapidosome component proteins. Rhapidosomes were incubated with $6 \mathrm{M} \mathrm{GHCl}$ at $80^{\circ} \mathrm{C}$ for $2 \mathrm{~h}$ at a final concentration of $1 \mathrm{mg} \mathrm{m}^{-1}$. Following treatment the rhapidosomes were diluted 50 -fold in a buffer containing $0.05 \mathrm{M}$ Tris $/ \mathrm{HCl}, 0.005 \mathrm{M}$ EDTA and $0.5 \mathrm{M} \mathrm{GHCl}$ for $2 \mathrm{~h}$. This sample was then dialysed twice against $0.05 \mathrm{M}$ Tris/ $\mathrm{HCl}, 0 \cdot 005 \mathrm{M}$ EDTA. The precipitate that formed during this procedure was sedimented by centrifugation and the supernatant was concentrated by Centricon- 30 membrane filters to a final concentration of $1 \mathrm{mg} \mathrm{ml}^{-1}$.

Transmission electron microscopy. This was performed as described previously (Pazirandeh et al., 1992).

Circular dichroism. Circular dichroism of the protein samples was measured over the wavelength range $250-190 \mathrm{~nm}$ using a Jasco J-600 spectropolarimeter. The cell used had an optical path length of $0.2 \mathrm{~mm}$. The experimental solutions contained $0 \cdot 1-0.3 \mathrm{mg}$ protein $\mathrm{ml}^{-1}$ in $0.05 \mathrm{M}$ Tris/ $\mathrm{HCl}$ buffer $\mathrm{pH} \mathrm{7.5}$. Blank measurement using the buffer solution did not show detectable circular dichroism.

The amount of different conformers present was estimated using ellipticity values of myoglobin as standard. The amounts of different conformers were estimated with an accuracy of $\pm 10 \%$.

Size-exclusion HPLC. This was performed using a Beckman System Gold HPLC equipped with a model 168 diode array detector and a TSK 4000SW (Toya Soda Inc.) column. Samples and calibration standards were analysed in $50 \mathrm{mM}$ Tris buffer (pH 7.5) containing $5 \mathrm{mM}$ EDTA at a flow rate of $0.5 \mathrm{ml} \mathrm{min} \mathrm{m}^{-1}$ while monitoring at $280 \mathrm{~nm}$. Calibration standards used were thyroglobulin, alcohol dehydrogenase, ovalbumin, myoglobin and vitamin $\mathrm{B}_{12}$ (Bio-Rad), and apoferritin, $\beta$-amylase, bovine serum albumin and carbonic anhydrase (Sigma). The column void corresponded to a molecular mass of over $2500 \mathrm{kDa}$.

\section{RESULTS AND DISCUSSION}

\section{Disruption of rhapidosomes into component proteins}

Rhapidosomes from Saprospira grandis were reported by Delk \& Dekker (1972) to be extremely stable structures and were not dissociated under a variety of conditions including treatment with $1 \mathrm{M} \mathrm{HCl}, 6 \mathrm{M} \mathrm{GHCl}\left(\right.$ at $25^{\circ} \mathrm{C}$ ), $8 \mathrm{M}$ urea or a range of organic solvents. The stability of rhapidosomes to a variety of harsh conditions is desirable for the use of these structures as a biomaterial. However, we were interested in finding conditions that would disrupt rhapidosomes, for subsequent in vitro self-assembly experiments. A number of reagents (Table 1) were tested for their ability to disrupt the rhapidosomes of $A$. itersonii. Rhapidosome preparations were treated with the various reagents and were subsequently analysed by electron microscopy and SDS-PAGE for the presence of intact rhapidosomes. The SDS-PAGE analysis utilizes the property of intact rhapidosomes (Pazirandeh \& Campbell, 1993) in which the component proteins do not dissociate and therefore do not enter the gel matrix unless boiled in solubilization buffer. As shown in Table 1 and Figs 1 and 2 , the only reagents that disrupted rhapidosomes into their component proteins were $0 \cdot 1 \mathrm{M} \mathrm{HCl}$ and $6 \mathrm{M} \mathrm{GHCl}$ (at $80^{\circ} \mathrm{C}$ for $2 \mathrm{~h}$ ): no rhapidosomes were observed by electron microscopy after treatment with these reagents (Fig. 1b, c) and only under these conditions did the rhapidosome component proteins enter the gel without boiling the samples in SDS solubilization buffer (Fig. 2, lanes 1 and 5).

\section{Renaturation and characterization of the rhapidosome component proteins}

Although treatment with either $\mathrm{HCl}$ or $\mathrm{GHCl}$ resulted in the disruption of rhapidosomes into their component proteins, treatment with the former reagent resulted in the immediate formation of a precipitate, indicating irreversible aggregation of the denatured proteins. Therefore all subsequent denaturation experiments were performed with GHCl. Dialysis of the denatured protein in aqueous buffer following $\mathrm{GHCl}$ treatment of rhapidosomes resulted in over $90 \%$ of the protein forming aggregates and less than $10 \%$ of the protein remaining in the soluble phase. A protocol was developed (see Methods) where the disrupted proteins were first rapidly diluted in $0.5 \mathrm{M}$ GHCl and subsequently dialysed against an aqueous buffer. Using this method only about $30 \%$ of the protein was found to be in the precipitated form (data not shown). The two factors, rapid dilution, and the presence of low concentrations of $\mathrm{GHCl}$, may allow intramolecular folding interactions to take precedence over intermolecular interactions as well as partially refold the proteins and destabilize 'wrong' aggregates or 'wrong intermediates on the folding pathway (Jaenicke \& Rudolph, 1990).

When these proteins were concentrated and analysed by SDS-PAGE and electron microscopy there was no 
Table 1. Disruption of rhapidosomes into component proteins

\begin{tabular}{|lcc|}
\hline Condition & \multicolumn{2}{c|}{ Disruption into component proteins* } \\
\cline { 2 - 3 } & SDS-PAGE & EM \\
\hline $\mathrm{HCl}(0 \cdot 1 \mathrm{M})$ & + & + \\
$\mathrm{NaOH}(0 \cdot 1 \mathrm{M})$ & - & - \\
$\mathrm{Chymotrypsin}(1 / 20, \mathrm{w} / \mathrm{w})$ & - & - \\
Urea $(8 \mathrm{M})$ & - & - \\
$\mathrm{GHCl}\left(6 \mathrm{M}, 80^{\circ} \mathrm{C}\right)$ & + & + \\
Butanol $(100 \%)$ & - & - \\
\hline
\end{tabular}

* Disruption was monitored by SDS-PAGE as well as by electron microscopy (EM) (see Methods).
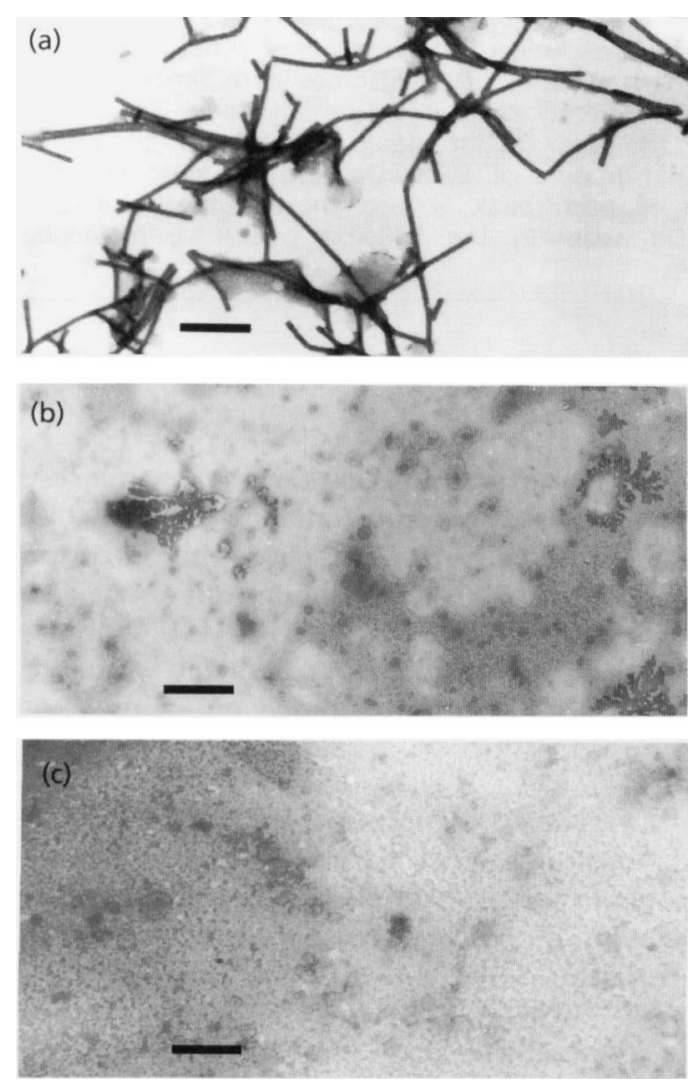

Fig. 1. Transmission electron microscopy of rhapidosomes after treatment with $\mathrm{HCl}$ and $\mathrm{GHCl}$. Rhapidosomes were treated with various reagents (see Methods and Table 1) and were then examined by electron microscopy for the presence of intact rhapidosomes. (a) Untreated rhapidosomes; (b) rhapidosomes treated with $\mathrm{HCl}$; (c) rhapidosomes treated with $\mathrm{GHCl}$. Not shown in this figure are rhapidosomes which were treated with $\mathrm{NaOH}, \mathrm{n}$-butanol, $8 \mathrm{M}$ urea, and chymotrypsin. Electron microscopy revealed the presence of intact rhapidosomes (similar to those seen in panel a) after treatment with these reagents. A minimum of 10 viewing fields were examined for samples treated with $\mathrm{HCl}$ and $\mathrm{GHCl}$ before concluding that there were no intact rhapidosomes present. Bars, $200 \mathrm{~nm}$.

evidence of rhapidosomes in these samples. However, circular dichroism spectra of the renatured rhapidosome proteins showed the presence of the following secondary

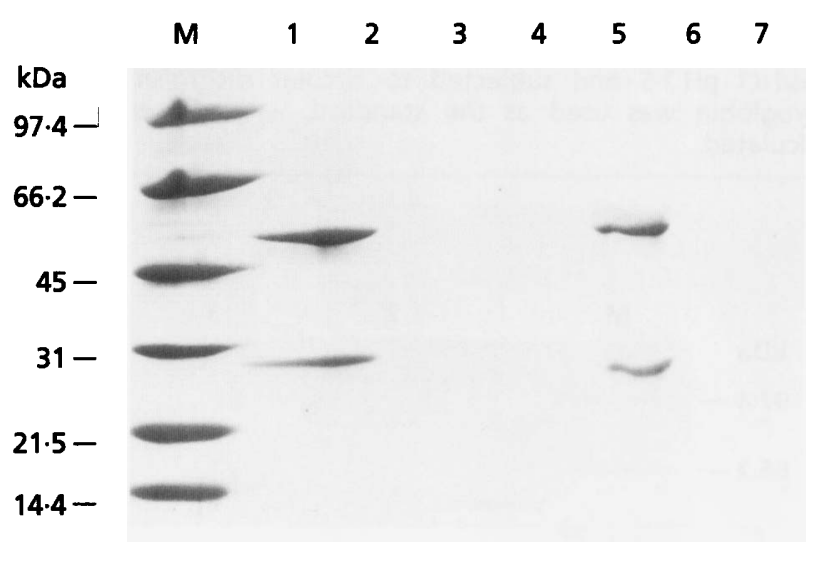

Fig. 2. SDS-PAGE of rhapidosomes after treatment with various reagents. Rhapidosomes $\left(1 \mathrm{mg} \mathrm{ml}^{-1}\right)$ were treated with the reagents listed below (see Methods) and subsequently analysed by SDS-PAGE. The samples were kept at room temperature (as opposed to being boiled) after the addition of the SDS-PAGE sample buffer. Lanes: $M$, molecular mass markers; $1,0.1 \mathrm{M} \mathrm{HCl}$; 2, $0.1 \mathrm{M} \mathrm{NaOH}$; 3, n-butanol; 4, $8 \mathrm{M}$ urea; 5, $6 \mathrm{M} \mathrm{GHCl}$; 6, chymotrypsin; 7, untreated rhapidosomes.

structures: $22.6 \%$ helix, $38.4 \%$ sheet, $16.5 \%$ turns and $23.4 \%$ random coil structures (Fig. 3). Further characterization revealed that the renatured proteins formed a complex of molecular mass $>100 \mathrm{kDa}$ as opposed to the proteins disrupted with $\mathrm{GHCl}$, which remained as monomers of molecular masses 53 and $29 \mathrm{kDa}$. This indication of complex formation was based on experiments where rhapidosomes denatured in the presence of $\mathrm{GHCl}$ as well as rhapidosomes which were denatured and subsequently renatured (by the rapid dilution method) were run through Centricon-100 filter membranes and both the upper and the lower fluids were then subjected to SDS-PAGE. As shown in Fig. 4 (lanes 1 and 2) in samples which had been denatured and subsequently renatured both the 29 and the $53 \mathrm{kDa}$ proteins remained exclusively in the top portion of the filter. This is in contrast to samples which had been denatured by $\mathrm{GHCl}$ (Fig. 4, lanes 3 and 4), in which the 29 and $53 \mathrm{kDa}$ protein bands are present in both the upper and lower portions of the Centricon membrane, indicating that both these proteins pass through the membrane (which has a cutoff of about 


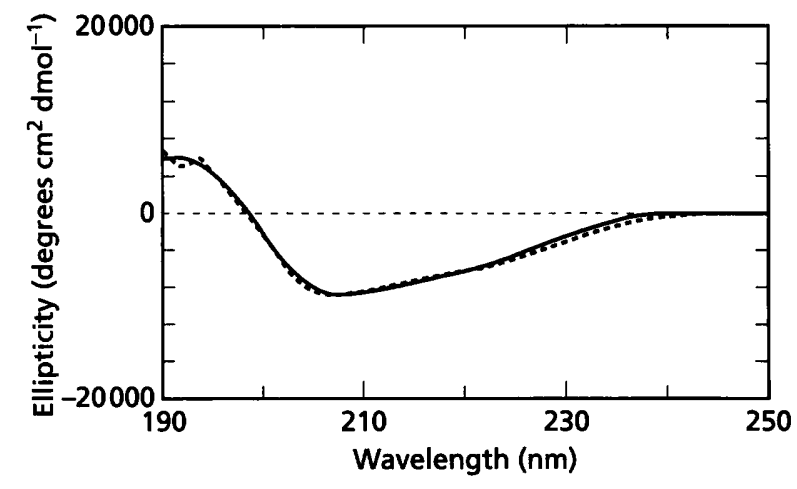

Fig. 3. Circular dichroism spectra of rhapidosome component proteins. Rhapidosomes were denatured with $\mathrm{GHCl}$ and subsequently renatured (see Methods). The sample was adjusted to a protein concentration of $0.1 \mathrm{mg} \mathrm{ml}^{-1}$ in $0.05 \mathrm{M}$ Tris/ $/ \mathrm{HCl} \mathrm{pH} 7.5$ and subjected to circular dichroism analysis. Myoglobin was used as the standard. - Observed;--.--., calculated.

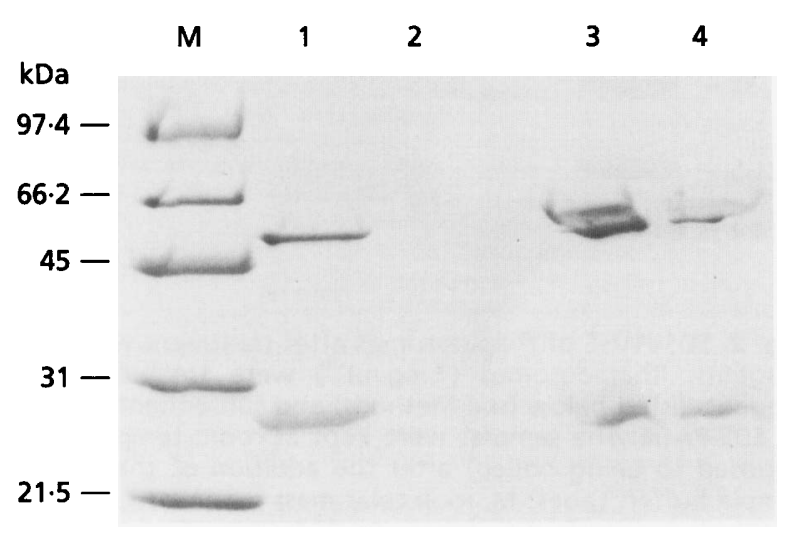

Fig. 4. SDS-PAGE analysis of denatured and renatured rhapidosomes after Centricon-100 filtration. Rhapidosomes were denatured with $\mathrm{GHCl}$ and a portion was subsequently renatured (see Methods). Both samples were run through Centricon-100 filters and then subjected to SDS-PAGE. Lanes: $M$, molecular mass markers; 1 , top portion of Centricon from renatured sample; 2, bottom portion of Centricon from renatured sample; 3 , top portion of Centricon from denatured sample; 4, bottom portion of Centricon from denatured sample.

$100 \mathrm{kDa}$ ). These data indicate that upon renaturation of the rhapidosomes the individual proteins have assembled into a higher molecular mass form (over $100 \mathrm{kDa}$ ) which prevents them from passing through the Centricon membranes. Furthermore when the renatured protein was subjected to either native PAGE or IEF it migrated as a single species (results not shown), a further indication of interaction between the two monomeric proteins. A pI of 4.9 was calculated for the complex.

To determine more precisely the molecular mass of this complex, the sample was subjected to size-exclusion

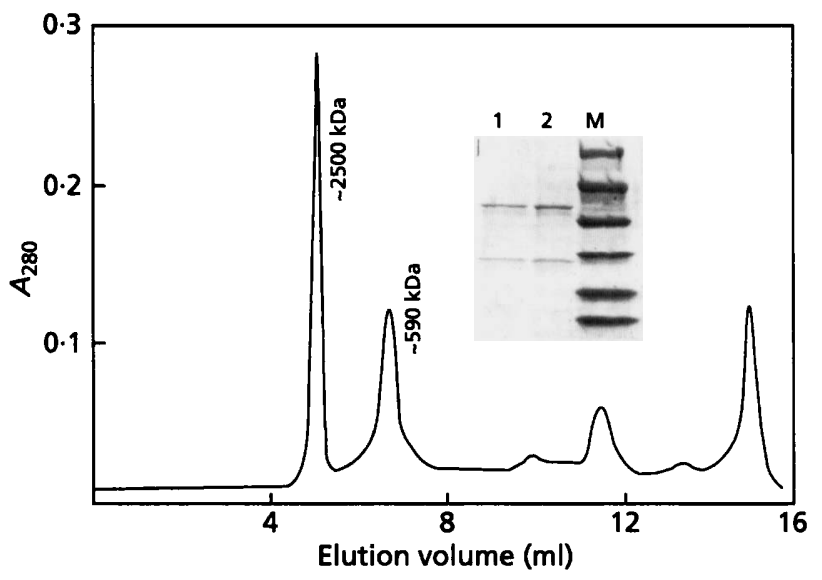

Fig. 5. Size-exclusion HPLC analysis of renatured rhapidosome component proteins. Rhapidosomes were denatured with $\mathrm{GHCl}$ and subsequently renatured (see Methods) and subjected to HPLC. The two major peaks correspond to approximate molecular masses of $2500 \mathrm{kDa}$ and $590 \mathrm{kDa}$. The SDS-PAGE profile of each peak is also shown (inset). Lanes: 1, the $2500 \mathrm{kDa}$ peak; 2 , the $590 \mathrm{kDa}$ peak; $\mathrm{M}$, molecular mass markers.

HPLC. Two high-molecular-mass complexes were observed, with apparent molecular masses of $590 \mathrm{kDa}$ and over $2500 \mathrm{kDa}$ (Fig. 5). These roughly correspond to aggregates consisting of six dimers and about 36 dimers (six of the smaller complex). SDS-PAGE analysis of the complex proteins revealed approximately equal ratios of the 29 and $53 \mathrm{kDa}$ proteins based on staining intensity (Fig. 5, inset).

Other self-assembling proteins, including the S-layer of bacteria and the secretory proteins of Chironomus tentans larvae, have been proposed to assemble in a stepwise fashion whereby an intermediate complex is formed prior to the assembly of the final product (Jaenicke et al., 1985; Sleytr et al., 1992; Takumi et al., 1991; Wellman \& Case, 1989). Whether the rhapidosome component proteins form a complex which is an intermediate in the pathway to rhapidosome formation remains to be established. Also to be established is the relationship of the two complexes $(590 \mathrm{kDa}$ and $>2500 \mathrm{kDa}$ ) and whether any other factors (ATP, GTP) or other self-assembly proteins need to be added to these intermediates for the production of rhapidosomes in vitro. We are currently conducting experiments to address these questions.

\section{REFERENCES}

Avila, J. (1990). Microtubule dynamics. F ASEB J 4, 3284-3290.

Chang, H. Y. \& Allen, M. M. (1974). The isolation of rhapidosomes from the blue-green alga, Spirulina. J Gen Microbiol 81, 121-130.

Correll, D. L. \& Lewin, R. A. (1964). Rod shaped ribonucleoprotein particles from Saprospira. Can J Microbiol 10, 63-74. 
Delk, A. S. \& Dekker, C. A. (1972). Characterization of rhapidosomes from Saprospira grandis. J Mol Biol 64, 287-295.

Evers, M. \& Murray, R. (1980). The comparison of rhapidosomes and defective bacteriophage particles from Aquaspirillum itersonii. Can J Microbiol 26, 1312-1319.

Jaenicke, R. \& Rudolph, R. (1990). Folding proteins. in Protein Structure: a Practical Approach, pp. 191-223. Edited by T. E. Creighton. New York: Oxford University Press.

Jaenicke, R., Welsch, R., Sara, M. \& Sleytr, U. B. (1985). Stability and self-assembly of the S-layer protein of the cell wall of Bacillus stearothermophilus. Biol Chem Hoppe-Seyler 366, 663-669.

Laemmli, U. K. (1970). Cleavage of structural proteins during the assembly of the head of bacteriophage T4. Nature 227, 680-685.

Pazirandeh, M. \& Campbell, J. (1993). Protein composition of rhapidosomes isolated from Aquaspirillum itersonii. J Gen Microbiol $139,859-864$.
Pazirandeh, M., Baral, S. \& Campbell, J. (1992). Metallized nanotubules derived from bacteria. Biomimetics 1, 39-48.

Sleytr, U. B., Pum, D., Sara, M. \& Messner, P. (1992). Two dimensional protein crystals as patterning elements in molecular nanotechnology. In AIP Conference Proceedings 262, Molecular Electronics - Science and Tecbnology. Edited by A. Aviram. New York: American Institute of Physics.

Takumi, K., Koga, T., Oka, T. \& Endo, Y. (1991). Self-assembly, adhesion, and chemical properties of tetragonally arrayed S-layer proteins of Clostridium. J Gen Appl Microbiol 37, 455-465.

Wellman, S. E. \& Case, S. T. (1989). Disassembly and reassembly in vitro of complexes of secretory proteins from Chironomus tentans salivary glands. $J$ Biol Chem 264, 10878-10883.

Received 25 November 1994; revised 27 February 1995; accepted 1 March 1995. 